\title{
MESOLITHIC AND NEOLITHIC HABITATION OF THE EASTERN BALTIC
}

ARVI LIIVA

Institute of Zoology and Botany, Estonian Academy of Sciences, Vanemuise Street 21

EE-2400 Tartu, Estonia

and

ILZE LOZE

Institute of Latvian History, 19, Turgenev Street, LV-1518 Riga, Latvia

\begin{abstract}
In this paper we consider the radiocarbon chronology of Mesolithic and Neolithic settlement sites in the eastern Baltic region. Dating of wood and charcoal from Estonian and Latvian sites establishes the periods (early, middle and late) within these epochs. We present $90{ }^{14} \mathrm{C}$ dates, as yet unpublished in RADIOCARBON, produced by laboratories in Riga, Tallin, Tartu, Leningrad and Moscow.
\end{abstract}

\section{INTRODUCTION}

The Tartu, Vilnius and Leningrad laboratories radiocarbon dated samples from Mesolithic and Neolithic settlement sites of the eastern Baltic. Laboratories in Riga, Tallinn and Moscow also dated some samples; Tartu and Leningrad previously reported 36 dates (Vinogradov et al. 1966; Liiva, Ilves and Punning 1966; Dolukhanov 1970; Ilves, Punning and Liva 1970; Semyontsov et al. 1972; Dolukhanov et al. 1976). We have used 90 additional dates for our study. All ${ }^{14} \mathrm{C}$ data presented here are uncorrected and uncalibrated.

\section{RADIOCARBON INVESTIGATIONS}

Radiocarbon investigations in the eastern Baltic have enabled us to establish an occupation history beginning with the Early Mesolithic. No samples were obtained from Late Paleolithic sites. The timing of the Early Mesolithic culture in Estonia and eastern Latvia was determined after dating seven samples from three habitation sites: Pulli in Estonia (5 samples), Zvejnieki II and Sūjagals in Latvia (2 samples). Occupation of the Pulli site, associated with the early phase of the Kunda culture, as are habitation sites of Latvia, is ascribed to 9600-9350 BP (Punning, Liiva and Ilves 1968; Ilves, Liiva and Punning 1974; Jaanits and Jaanits 1978).

The Pulli habitation site, located in the lower reaches of the Pärnu River, demonstrates stratigraphic peculiarities. The cultural layer lies in black humus, which underlies a 1-m-thick ribbon-shaped stratum of organic matter and clay, covered with a 2-m-thick sand layer. The latter formed during the Lake Ancylus period (Jaanits and Jaanits 1975, 1978). Archaeological material, represented by flint, bone and antler artifacts, is characteristic of the Early Mesolithic. The following dates were obtained from the Pulli habitation site: $9600 \pm 120$ BP to $9350 \pm 60$ BP (TA-245, TA-949); the lake-bog deposits were dated from $9300 \pm 75 \mathrm{BP}$ and $9285 \pm 120 \mathrm{BP}$ (TA-175, TA-284). Pollen analysis enabled us to assign the Pulli habitation site to the Preboreal climatic period.

The Early Mesolithic of the Zvejnieki II habitation site was dated from one sample to $8500 \pm 460$ BP (Tln-296) (Loze and Liiva 1990). Zvejnieki II is located in the region of drumlins on the bank of the Rūja at its discharge into Lake Burtnieku, northern Latvia. The Early Mesolithic layer, 0.7-1.0 m thick, consists of gravel mixed with lake lime and is overlain by a Middle Mesolithic layer, $0.30-0.35 \mathrm{~m}$ thick (Zagorskis 1973). The assemblage of this layer is characteristic of the Early Mesolithic (Zagorska 1981). 
The sample from the Sūlagals habitation site, southeast of Lake Lubāna in the ancient lake, dated to $9575 \pm 80 \mathrm{BP}$ (TA-1317) (Loze 1982, 1988; Loze and Liiva 1990). The geomorphology of the site showed that, in its lower section, limnoglacial clay was uncovered, overlain by light, fine-grained sand formed in periglacial and glacial basins. Fine- and coarse-grained sand and gravel, alternating with dark-gray sand lenses, constituted the Holocene deposits, which contained the wood sample used for dating (Loze 1988; Eberhards 1989). The assemblage from this site consisted of flint, bone and antler artifacts which characterized the Early Mesolithic, and enabled us to assign the site to the Preboreal climatic period (Loze 1988).

To define the ${ }^{14} \mathrm{C}$ chronology of the Middle Mesolithic, we use two ${ }^{14} \mathrm{C}$ dates from the type locale of the Kunda culture, the Kunda-Lammasmägi site in Estonia, and the Zvidze site in the Lubāna Lowland in Latvia. Charcoal was sampled from a cultural layer at Kunda-Lammasmägi, located on an island in Ancylus Lake, and dated at $8340 \pm 280$ BP (TA-14) (Liiva, Ilves and Jaanits 1965; Jaanits 1965, 1966; Ilves, Liiva and Punning 1974). At Zvidze, in the northwestern part of the Lubāna Lowland, at 1.55-1.60-m depth in fine-grained sand under bog deposits, a bâton de commande, or Kunda gaff, and other artifacts characteristic of the Middle Mesolithic were found. Pollen analysis showed that the primary occupation of the Zvidze site was during the Middle Mesolithic (Loze 1988).

A sapropel sample was dated at $7650 \pm 100 \mathrm{BP}$ (Middle Mesolithic) (TA-1722) (Loze 1988; Loze and Liiva 1990), which, according to pollen analysis performed by I. Jakubovska and V. Stelle, belongs to the second half of the Boreal period. Two additional dates, $7480 \pm 80 \mathrm{BP}$ and $7370 \pm$ 90 BP (TA 1745, TA-857), may be related to the Middle Mesolithic (Loze and Liiva 1990). It is easier to determine the time range of the Late Mesolithic culture at Zvidze because 11 dates were obtained. Further, several samples from the Zvidze, Narva and Osa sites were dated from sections where pollen data were obtained. The Late Mesolithic occupation at Zvidze dates to 7200/71006630/6530 BP (Loze 1988). These samples date earlier than at the Narva and Osa sites in the Lake Lubāna depression, where the range of dates is broader: $7640 \pm 180 \mathrm{BP}$ to $5300 \pm 250 \mathrm{BP}$ (TA-53, TA-7) (Liiva, Ilves and Jaanits 1965; Liiva, Ilves and Punning 1966; Ilves, Liiva and Punning 1974). Dates from the Osa site serve as a basis for dating Late Mesolithic occupation in the Lake Lubāna depression. The range of dates from Osa, $7180 \pm 60 \mathrm{BP}$ to $6578 \pm 70 \mathrm{BP}(\mathrm{B} \ln -770, \mathrm{LE}-810)$ (Zagorskis et al. 1984), correlates with Zvidze dates (Loze and Liiva 1990).

On a slope at the Zvidze site, cultural layers formed in peat, sapropel and gravel, reaching 1.8-2.0 $\mathrm{m}$ thickness. Previous data obtained by Loze (1982) indicated that the Late Mesolithic occupation occurred in the first half of the Atlantic climatic period (Loze 1988). We measured ten ${ }^{14} \mathrm{C}$ dates from samples in this section, which were also analyzed for pollen; two dates related to the first half of the Atlantic climatic period (Loze 1988). From the Narva site, three Late Mesolithic cultural layers were uncovered, separated from each other by layers of sterile sand (Jaanits 1965, 1966). At the Osa site, located on a terrace formed during the Preboreal transgression of Lake Lubanna, the cultural layer, as at Zvidze, lay under the Early Neolithic stratum (Zagorskis 1973; Zagorskis et al. 1984).

The beginning of the Neolithic in the eastern Baltic is characterized by the appearance of ceramics.

${ }^{14} \mathrm{C}$ dates for the Early Neolithic, like those for the Mesolithic, were obtained only in Latvia, Estonia and Kaliningrad. The earliest phase of the Early Neolithic Narva culture was dated on 27 samples obtained from the Zvidze and Osa sites (Loze and Liiva 1989). These dates fall into three phases: $6450 \mathrm{BP}$ to $6210 / 6110 \mathrm{BP}, 6195 \mathrm{BP}$ to $5320 \mathrm{BP}$, and $5320 \mathrm{BP}$ to $4905 \mathrm{BP}$ (Loze 1988). Five results from Osa date the Early Neolithic layer to $6533 \pm 120 \mathrm{BP}$ to $5730 \pm 50 \mathrm{BP}(\mathrm{Ri}-272, \mathrm{LE}-850)$ (Loze 1988). 
The later phase of the Narva culture is based on seven dates from the Kääpa site and one from the Zvejsalas site in Estonia and Latvia, as well as nine dates from Cedmar A in the Kaliningrad area (Loze and Liiva 1989). Kääpa dates covered the interval of $4865 \pm 235 \mathrm{BP}$ to $4640 \pm 100 \mathrm{BP}$ (TA-5, TA-815) (Loze and Liiva 1989). This is somewhat later than that determined for later Narva culture samples from the Lake Lubanna depression. The Kääpa site is on the Vihandu River in southeastern Estonia, with a cultural layer $0.5 \mathrm{~m}$ thick (Jaanits 1965). Dates from Cedmar A range from $5280 \pm 50$ BP to $4920 \pm 80 \mathrm{BP}$ (Bln-2162, LE-1388) (Timofeev 1984, 1987). From pollen data, the Zvidze, Osa, Kääpa and Cedmar A occupations date to the second half of the Atlantic.

Middle Neolithic chronology of the eastern Baltic is based on dates obtained from the Lake Lubāna basin (Zvidze, Piestinga and others) and the Šventoji and Sărnate sites. Four ${ }^{14} \mathrm{C}$ results from the Zvidze Middle Neolithic define two cultures: Comb-and-Pit-Marked Pottery and Eastern Baltic; the dates range from $4750 \pm 60 \mathrm{BP}$ to $4370 \pm 80 \mathrm{BP}$ (TA-1801, TA-675) (Loze 1988). Influx of the Comb-and-Pit-Marked Pottery culture into the Lake Lubāna basin could have occurred from 4950 BP to 4750 BP, although more data are needed. In the Zvidze and Osa sites, Comb-and-Pit-Marked Pottery assemblages were found above Early Neolithic layers.

Nine ${ }^{14} \mathrm{C}$ dates were obtained from two Middle Neolithic sites on the Baltic coast: Sārnate, near Ventspils, Latvia and Šventoji, north of Palanga, Lithuania. Five dates from Sārnate indicate an occupation interval of $4700 \pm 250$ BP to $4510 \pm 110$ BP (TA-26, TA-814) (Vankina 1970; Loze and Liiva 1989). Results from Šventoji indicate occupation from $4640 \pm 60 \mathrm{BP}$ to $4400 \pm 90 \mathrm{BP}$ (Lj-2528, TA-247) (Rimantienè 1979, 1984; Loze and Liiva 1989; Timofeev 1988). The Šventoji 1B and 2B sites also yielded younger dates, $4100 \pm 60 \mathrm{BP}$ and $4190 \pm 80 \mathrm{BP}$ (LE-833, Vil-1) (Rimantiene 1979, 1984). Thus, the Middle Neolithic occupation in the eastern Baltic seems to have occurred from 4700 to 4400 BP. However, in eastern Latvia, the Comb-and-Pit-Marked Pottery culture was also found on a stratum above the Narva occupation.

The Late Neolithic in the eastern Baltic is represented by dates from Lake Lubāna sites (Abora I, Eiņi, Iča and Lagaža) (Loze 1979), as well as those from Šventoji and Nida in Lithuania. The period is represented by a mixed assembly of a flint and stone industry, amphoras, beakers and vessels characteristic of the Cord Pottery culture (Loze 1979). Seven samples from the Lake Lubāna sites date the Late Neolithic in eastern Latvia: $4490 \pm 80 \mathrm{BP} / 4250 \pm 100 \mathrm{BP}$ (TA-2144, TA-2145) to $3640 \pm 70 \mathrm{BP}$ (TA-382, TA-396) (Loze 1988). The Šventoji sites, with materials of the Rzucewo culture, date to $4120 \pm 80 \mathrm{BP}-3860 \pm 50 \mathrm{BP}$ (TA-246, LE 835) (Rimantiene 1980, 1984). The Nida site (also containing the Rzucewo complex) at Kuršiu spit dated at $4460 \pm 110$ $\mathrm{BP}-4070 \pm 50 \mathrm{BP}$ (Vs-632, Bln-2592) (Rimantiene 1989). The final stage of Nida occupation is dated from $3470 \pm 70$ BP (Vs-320) (Rimantienè 1989), although, according to Early Bronze Age Lubāna-type pottery complex, including bronze melting crucibles found at Lagaža, the Late Neolithic-Early Bronze Age transition is ascribed to $3640 \pm 70$ BP (TA-382, TA-396) (Loze 1979).

Several ${ }^{14} \mathrm{C}$ dates were also obtained from Late Neolithic sites on the shore of Lake Biržulis in northwestern Lithuania; the earliest date from $4260 \pm 110 \mathrm{BP}$ to $4040 \pm 50 \mathrm{BP}$ (Vs-318, LE-1787), and the latest, $3770 \pm 100 \mathrm{BP}$ (Vs-363) (Butrimas 1985). Other results from sites on Lake Kretuonas (eastern Lithuania) date occupation at $3710 \pm 160$ BP and $3570 \pm 120$ BP (Vs-312, Vs-311) (Girininkas 1983).

\section{CONCLUSION}

Our understanding of eastern Baltic Mesolithic and Neolithic settlements has grown as a result of

${ }^{14} \mathrm{C}$ dating combined with studies of stratigraphy, ceramic and artifact typology and pollen spectra 
analyses. Six periods of occupation have been distinguished (three Mesolithic and three Neolithic), as well as durations of two Mesolithic cultures and two Neolithic ceramic-producing cultures.

\section{REFERENCES}

Butrimas, A. J. (ms.) 1985 The Late Neolithic of the Zemaitija Highland (Based on materials of monuments of Lake Birzulis): Ph. D. Thesis. Vilnius, $24 \mathrm{p}$.

Dolukhanov, P. M. 1970 Khlopin Institute radiocarbon dates II. Radiocarbon 12(1): 130-155.

Dolukhanov, P. M., Simyontsov, A. A., Svezhentsev, Yu. S., Timofeyev, V. I., Romanova, Ye. N. and Malanova, N. S. 1976 Radiocarbon dates of the Institute of Archaeology III (sic). Radiocarbon 18(2): 190-210.

Eberhards, G. 1989 New data on the geomorphology of Stone Age sites of the Lubāna lowland (Mesolithic, Early and Middle Neolithic). Proceedings of the Latvian Academy of Sciences 2: 74-85.

Grininkas, A. A. (ms.) 1983 The Late Neolithic of Eastern Lithuania (Thesis of reports on Lake Kretuonas): Ph. D. Thesis, Vilnius, 22 p.

Ilves, E., Liiva, A. and Punning, J.-M. 1974 The Radiocarbon Method and its Application in Quaternary Geology and Archaeology of Estonia. Tallinn, Estonian Academy of Sciences.

Ilves, E., Punning, J.-M. and Liiva, A. 1970 Tartu radiocarbon dates IV. Radiocarbon 12(1): 238-248.

Jaanits, L. 1965 On results of the Stone Age investigations in Soviet Estonia. Finskt Museum 72: 5-46.

1966 New data on the Mesolithic of Estonia - by the sources of ancient cultures. Materials and Investigations in Archaeology of the USSR 126: 114-123.

Jaanits, L. and Jaanits, K. 1975 The Pulli Early Mesolithic habitation site. Proceedings of Estonian SSR Academy of Sciences, Social Science 1: 64-70.

1978 Excavations of the Pulli Early Mesolithic habitation site. Proceedings of Estonian SSR Academy of Sciences, Social Science 27: 56-63.

Liiva, A. A., Ilves, E. O. and Jaanits, L. J. 1965 Radiocarbon dating of some archaeological sites of the Baltic. Archaeology and Natural Sciences: 46-50.

Liiva, A., Ilves, E. and Punning, J.-M. 1966a List of radiocarbon datings of the Institute of Zoology and Botany, Estonian SSR Academy of Sciences. Proceedings of the Estonian SSR Academy of Sciences, Biology Series 15(1): 112-121.

1966b Tartu radiocarbon dates I. Radiocarbon 8: 430-441.

Loze, I. A. 1979 The Late Neolithic and Early Bronze Age of the Lubāna Plain. Riga, Qinatne: 204 p.

1982 Radiocarbon dates of the Stone Age sites of the Lubāna lowland. Proceedings of Latvian SSR Academy of Sciences 8: 36-45.

1988 The Stone Age Habitation Sites of the Lubāna Lowland, the Mesolithic, Early and Middle Neolithic. Riga, Qinátne: 211 p.

Loze, I. A. and Liiva, A. A. 1989 Chronology of the
Early Neolithic of the Eastern Baltic (Thesis of reports on habitation sites). Proceedings of the Latvian SSR Academy of Sciences 2: 50-67.

1990 Radiocarbon dates of the Mesolithic of the Eastern Baltic (Thesis of reports on habitation sites). Proceedings of the Latvian SSR Academy of Sciences 10: 78-85.

Loze, I. A., Liiva, A. A., Stelle, V. J., Eberhards, G. J. and Jakubovskaja, I. J. 1984 Zvidze - A multilayer habitation site of the Mesolithic and Neolithic in the Lubāna Lowland. In Archaeology and Paleogeography of the Mesolithic and Neolithic of the Russian Plain. Moscow: 40-55.

Punning, J.-M., Liiva, A. and Ilves, E. 1968 List of radiocarbon dates of the Institute of Zoology and Botany, Estonian SSR Academy of Sciences, Report III. Bulletin of the Estonian SSR Academy of Sciences, Biology 18(4): 426-430.

Rimantienè, R. 1979 Sventoji, Habitation Sites of the Narva Culture. Vilnius, Mokslas: 188 p.

1980 Sventoji, Habitation Sites of the Littoral Culture. Vilnius, Mokslas: $87 \mathrm{p}$. 343 p.

1984 Stone Age of Lithuania. Vilnius, Mokslas:

1989 Nida, Habitation Site of Ancient Balts. Vilnius, Mokslas $211 \mathrm{p}$.

Semyontsov, A. A., Dolukhanov, P. M., Romanova, Ye. N. and Timofeyev, V. I. 1972 Radiocarbon dates of the Institute of Archaeology III. Radiocarbon 14(2): 336-367.

Timofeev, V. I. 1984 On the Early Neolithic links between the East Baltic area and Fenno-Scandia. ISKOS 4: 36-41.

1987 On the problem of the Early Neolithic of the East Baltic area. Acta Archaeologica 58: 207-212.

Vankina, L. 1970 Särnate Peat Bog Habitation Site. Riga, Qinátne: $176 \mathrm{p}$.

Vinogradov, A. P., Devirts, A. L., Dobkina, E. I. and Markova, N. G. 1966 Radiocarbon dating in the Vernadsky Institute I-IV. Radiocarbon 8: 292-323.

Zagorska, I. 1981 The Early Mesolithic in Latvia. Reports of the Potsdam Ancient History Museum 14/15: 73-82.

Zagorskis, F. 1973 The Late Mesolithic in Latvia. In Kozlowski, S. K., ed., The Mesolithic in Europe. Warsaw University Press, Warsaw: 651-669.

Zagorskis, F., Eberhards, G. J., Stelle, V. J. and Jakubovskaja, I. J. 1984 Osa - A multilayer habitation site of the Mesolithic and Neolithic in Lubăna Lowland. In Archaeology and Paleogeography of the Mesolithic and Neolithic of the Russian Plain. Moscow: 55-67. 